\title{
Correction to: The results of decompression of the musculocutaneous nerve entrapment in children with obstetric brachial plexus palsy
}

\author{
Tüzün Fırat ${ }^{1}$ (D) $\cdot$ Kıvanç Delioğlu ${ }^{1} \cdot$ Yasin Tunç ${ }^{1} \cdot$ Akın Üzümcügil $^{2} \cdot$ Mehmet Yörübulut $^{3} \cdot$ Gürsel Leblebicioğlu $^{4}$
}

Published online: 5 September 2020

(C) Springer-Verlag GmbH Germany, part of Springer Nature 2020

\section{Correction to: Child's Nervous System https://doi.org/10.1007/s00381-020-04828-8}

The original version of this article unfortunately contained an error. Tables and Supplementary are incorrectly processed during production. Given in this article are the correct tables.

The online version of the original article can be found at https://doi.org/ $10.1007 / \mathrm{s} 00381-020-04828-8$

Tüzün Firat

tuzun75@gmail.com; tuzun@hacettepe.edu.tr

1 Faculty of Physical Therapy and Rehabilitation, Hacettepe University, Altındağ, Ankara, Turkey

2 Department of Orthopaedics and Traumatology, Faculty of Medicine, Hacettepe University, Sıhhiye, Ankara, Turkey

3 Department of Radiology, Acıbadem Hospital, Çankaya, Ankara, Turkey

4 Hand Clinic, Rabindranath Tagore Street, Çankaya, Ankara, Turkey 
Table 1 Characteristics and findings of the patients

\begin{tabular}{|c|c|c|c|c|c|c|c|}
\hline Patients & Sex & $\begin{array}{l}\text { Injury } \\
\text { side }\end{array}$ & MRI finding & Surgical finding & Narakas type & $\begin{array}{l}\text { Age of surgery } \\
\text { (month) }\end{array}$ & $\begin{array}{l}\text { Birth } \\
\text { weight }(g)\end{array}$ \\
\hline 1 & M & $\mathrm{R}$ & $\begin{array}{l}\text { Inflamed part of the MCN in on the proximal part } \\
\text { of the arm, at the conjoint part of the biceps tendons }\end{array}$ & Compression under the conjoint tendon & $2 \mathrm{a}$ & 8 & 3970 \\
\hline 2 & $\mathrm{~F}$ & $\mathrm{R}$ & $\begin{array}{l}\text { Inflammation of the MCN at the conjoint part } \\
\text { of the biceps tendons }\end{array}$ & Compression under the conjoint tendon & $2 \mathrm{a}$ & 15 & 3960 \\
\hline 3 & $\mathrm{~F}$ & $\mathrm{~L}$ & $\begin{array}{l}\text { Inflammation of the } \mathrm{MCN} \text { at the conjoint part of the } \\
\text { biceps tendons }\end{array}$ & Compression under the conjoint tendon & $2 \mathrm{a}$ & 16 & 3300 \\
\hline 4 & $\mathrm{~F}$ & $\mathrm{R}$ & $\begin{array}{l}\text { Inflammation of the } \mathrm{MCN} \text { in on the proximal part } \\
\text { of the arm, at the conjoint tendons of coracobrachialis } \\
\text { and biceps short head }\end{array}$ & $\begin{array}{l}\text { Compression between middle and distal } \\
\text { tendon of biceps short head }\end{array}$ & $2 \mathrm{a}$ & 13 & 3450 \\
\hline 5 & M & $\mathrm{R}$ & $\begin{array}{l}\text { Inflammation of the MCN at the conjoint part of the } \\
\text { biceps tendons }\end{array}$ & $\begin{array}{l}\text { Compression under the middle part of } \\
\text { biceps short head tendon }\end{array}$ & $2 b$ & 10 & 4200 \\
\hline 6 & M & $\mathrm{R}$ & $\begin{array}{l}\text { Inflammation of the MCN at the conjoint tendons } \\
\text { of coracobrachialis and biceps short head }\end{array}$ & $\begin{array}{l}\text { Compression under the middle part of } \\
\text { biceps short head tendon }\end{array}$ & $2 \mathrm{a}$ & 9 & 3430 \\
\hline 7 & M & $\mathrm{R}$ & $\begin{array}{l}\text { Inflammation of the MCN at the conjoint tendons } \\
\text { of coracobrachialis and biceps short head }\end{array}$ & Compression under conjoint tendon & $2 b$ & 8 & 5000 \\
\hline 8 & $\mathrm{~F}$ & $\mathrm{~L}$ & $\begin{array}{l}\text { Inflammation of the } \mathrm{MCN} \text { in on the proximal part } \\
\text { of the arm }\end{array}$ & $\begin{array}{l}\text { Compression under the middle part of } \\
\text { biceps short head tendon }\end{array}$ & $2 b$ & 11 & 3390 \\
\hline 9 & M & $\mathrm{L}$ & $\begin{array}{l}\text { Inflammation of the MCN at the conjoint tendons } \\
\text { of coracobrachialis and biceps short head }\end{array}$ & $\begin{array}{l}\text { Compression under the middle part of } \\
\text { biceps short head tendon }\end{array}$ & $2 a$ & 9 & 4200 \\
\hline 10 & $\mathrm{~F}$ & $\mathrm{R}$ & $\begin{array}{l}\text { Inflammation of the } \mathrm{MCN} \text { at the conjoint tendons of } \\
\text { coracobrachialis and biceps short head }\end{array}$ & $\begin{array}{l}\text { Compression under the middle part } \\
\text { of biceps short head tendon }\end{array}$ & $2 a$ & 10 & 4100 \\
\hline 11 & M & $\mathrm{R}$ & $\begin{array}{l}\text { Inflammation of the MCN in on the proximal part of } \\
\text { the arm, at the conjoint tendons of coracobrachialis } \\
\text { and biceps short head }\end{array}$ & $\begin{array}{l}\text { Compression under the middle part } \\
\text { of biceps short head tendon }\end{array}$ & $2 a$ & 11 & 4150 \\
\hline
\end{tabular}

Table 2 Comparison of the elbow and shoulder movements between the three different assessments

\begin{tabular}{|c|c|c|c|c|c|c|c|c|c|c|}
\hline \multirow[t]{2}{*}{ Active Movement Scale Scores } & \multicolumn{3}{|l|}{ Pre-Op } & \multicolumn{3}{|c|}{ Post-Op 3 months } & \multicolumn{3}{|c|}{ Post-Op 1 year } & \multirow[t]{2}{*}{$\mathrm{p}$} \\
\hline & Median & Min/Max & IQR & Median & $\operatorname{Min} / \operatorname{Max}$ & IQR & Median & $\operatorname{Min} / \operatorname{Max}$ & IQR & \\
\hline Elbow Flexion & 2 & $1 / 2$ & 1 & 3 & $3 / 4$ & 1 & 5 & $5 / 6$ & 1 & $0.0001^{\mathrm{a}, \mathrm{b}, \mathrm{c}}$ \\
\hline Shoulder Abduction & 5 & $3 / 6$ & 1 & 5 & $4 / 6$ & 1 & 5 & $5 / 6$ & 1 & $0.002^{\mathrm{b}}$ \\
\hline
\end{tabular}

${ }^{\text {a }}$ Statistically difference between Pre-Op and Post-Op 3 months after Bonferroni Correction

${ }^{\mathrm{b}}$ Statistically difference between Pre-Op and Post-Op 1 year months after Bonferroni Correction

${ }^{\mathrm{c}}$ Statistically difference between Post-Op 3 months and Post-Op 1 year months after Bonferroni Correction

$I Q R$ Inter quartile range 


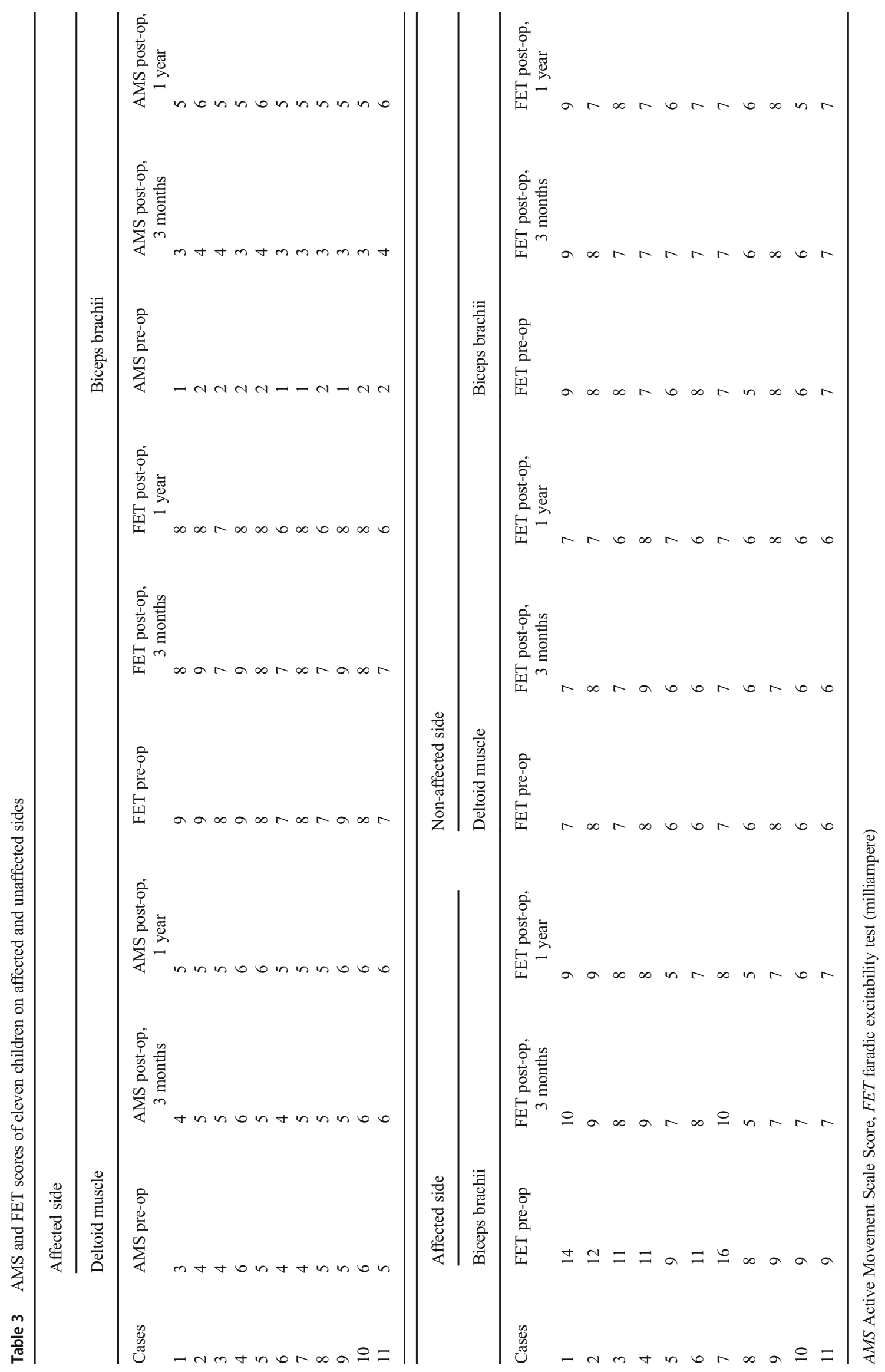


Table 4 Comparison of the faradic test values between the three different assessments

\begin{tabular}{lllll}
\hline $\begin{array}{l}\text { Faradic excitability test values } \\
(\mathrm{mA})\end{array}$ & $\begin{array}{l}\text { Pre-op, } \\
X \pm \mathrm{SD}\end{array}$ & $\begin{array}{l}\text { Post-op, 3 months, } \\
X \pm \mathrm{SD}\end{array}$ & $\begin{array}{l}\text { Post-op, 1 year, } \\
X \pm \mathrm{SD}\end{array}$ & $p$ \\
\hline Biceps brachii & $10.81 \pm 2.44$ & $7.9 \pm 1.51$ & $7.18 \pm 1.4$ & $0.0001^{\mathrm{a}, \mathrm{b}}$ \\
Deltoid muscle & $8.09 \pm 0.83$ & $7.9 \pm 0.83$ & $7.36 \pm 0.92$ & $0.002^{\mathrm{b}, \mathrm{c}}$ \\
\hline
\end{tabular}

${ }^{\text {a }}$ Statistical difference between pre-op and post-op 3 months after Bonferroni correction

b Statistical difference between pre-op and post-op 1 year months after Bonferroni correction

${ }^{\mathrm{c}}$ Statistical difference between post-op 3 months and post-op 1 year months after Bonferroni correction $X \pm S D$ mean \pm standard deviation, $m A$ milliampere

Publisher's note Springer Nature remains neutral with regard to jurisdic-

tional claims in published maps and institutional affiliations. 